\title{
SCIENCE AND TECHNOLOGY
}

Article citation info:

MACIÁN V, TORMOS B, RIECHI J. Time replacement optimization model: comparative analysis of urban transport fleets using Monte Carlo Simulation. Eksploatacja i Niezawodnosc - Maintenance and Reliability 2017; 19 (2): 151-157, http://dx.doi.org/10.17531/ein.2017.2.1.

\author{
Vicente MACIÁN \\ Bernardo TORMOS \\ Jorge RIECHI
}

\section{TIME REPLACEMENT OPTIMIZATION MODEL: COMPARATIVE ANALYSIS OF URBAN TRANSPORT FLEETS USING MONTE CARLO SIMULATION}

\section{MODEL OPTYMALIZACJI CZASU WYMIANY FLOTY. ANALIZA PORÓWNAWCZA FLOT MIEJSKIEGO TRANSPORTU PUBLICZNEGO Z ZASTOSOWANIEM SYMULACJI MONTE CARLO}

\begin{abstract}
This paper presents a comparative analysis of operation and maintenance costs of the transport fleets in two countries: Spain and Brazil. For this analysis, the research proposed an optimization model which is a combination of the traditional Life Cycle Cost Analysis methodology (LCC) and simulation model Monte Carlo. The results indicated the successful of model and show the lower cost in the Brazilian fleet. The evidences may be useful for other practices and researches.
\end{abstract}

Keywords: maintenance costs, life cycle cost, Monte Carlo Simulation, fleet replacement.

W niniejszej pracy przedstawiono analizę kosztów pracy i utrzymania flot transportowych $w$ dwóch krajach: Hiszpanii i Brazylii. Dla celów analizy, zaproponowano model optymalizacji stanowiacy połaczenie tradycyjnej Analizy Kosztów Cyklu Życia (LCC) oraz modelu symulacji Monte Carlo. wyniki potwierdzity trafność modelu oraz pokazały, że koszty ponoszone w przypadku floty brazylijskiej były niższe. Zaproponowany model może znaleźć zastosowanie zarówno $w$ praktyce jak $i$ w dalszych badaniach.

Stowa kluczowe: koszty utrzymania ruchu, koszty cyklu życia, symulacja Monte Carlo, wymiana floty.

\section{Introduction}

"Replacement decision" is a classical operation research topic in the industrial engineering. The replacement theory can indicate the optimal equipment life. "Optimal life" can be defined as the period between the time when the equipment comes into service and the time when it should be replaced due economic reasons. The operating cost of an equipment or asset generally rises as their condition deteriorates over time. When the cost reaches a certain level, the long-run costs associated with investment in a new equipment become less than those if keeping the old equipment [6]. At this point, replacement is carried out. Thus, a basic replacement analysis usually examines both the trend in operating and maintenance costs (O\&M) and the net cost of replacement, which is defined as the difference between the cost of the new equipment and the salvage value of the old one. In some cases, the replacement analysis also considers the resale value of the equipment at various stages of its service life.

For fleet replacement, the literature suggests two kinds of models: economic engineering (EE) and operational research (OR) models[12, 16]. EE models are restricted to economic and financial aspects, with technological, management and strategic variables considered as exogenous. This limitations force management to avoid formal investment analysis and to use unstructured subjective analysis [5]. Traditional OR models focus on a single objective to be maximized/minimized by modeling multiple variables. These methodologies are complemented by a management tool used for decision-making known as conventional Life Cycle Cost Analysis (LCC)[2]. According to Nowakowski [15] and other authors [7, 18], mathematical models of life cycle costs can be classified into three basic groups:

- models dedicated to technical objects' manufacturers that are designed to minimize the costs that occurred in the early stages of its lifetime,

- models aimed to minimize the lifetime cost of the facilities already in operation,

- models oriented to customers willing to purchase a new technical object.

The main area of the authors' interest is the last group of models, which is useful to define the future costs. Furthermore, in this for transport fleet applied model, the LCC is based on engineering economics to identify a point of a given asset's life at which the cumulative cost of operating $(\mathrm{O})$, maintenance $(\mathrm{M})$ and ownership reaches its minimum value. According to Fan and Jin [9], the most widely accepted approach is called the "cost minimization method". Gransberg and O' Connor [11] describe it as 'the most appropriate analysis method" and proposes that it "yields an optimum replacement timing cycle and a corresponding Equivalent Annual Cost (EAC)". In order to establish their useful life, particularly for buses, it is of key importance the understanding of the concepts explained in the following figure 1. 


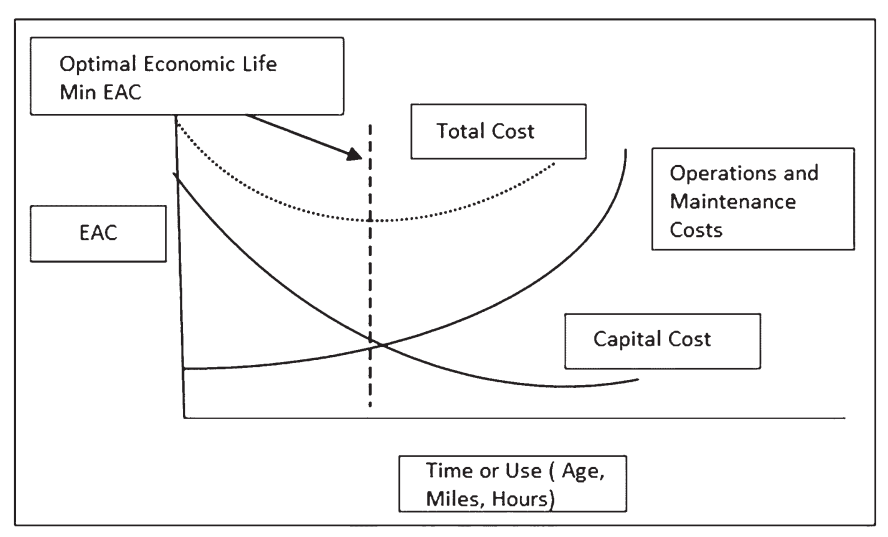

Fig. 1. Equivalent Annual Cost

The theoretical optimum service life is the point at which cumulative costs are at the minimum and it defines the economic life. From a financial standpoint, the cost object of minimum life cycle is the ideal age of retirement and/or replacement. This age can be shown in years of life or mileage travelled. This analysis has to be subject to the same working conditions, in order to observe a similar trend. According to the asset type, design specifications and the service to be performed, it is clear that in most cases total vehicle mileage is a better indication of asset aging than the vehicle's age.

A viable alternative to conduct a LCC study on vehicles is to use an economic engineering criterion in conjunction with optimization models $[4,13,14]$. Depending on the type of vehicles in a fleet, optimization models can be divided into two categories: homogeneous and heterogeneous $[3,10]$. In homogeneous models, the main objective is to find the best time for the replacement of a set of identical vehicles (same type and age) that must be replaced together; this is also known as the "no cluster splitting rule". These models are usually developed using a dynamic programming approach. Heterogeneous models are more appropriate when different types of vehicles need to be optimized simultaneously or when there are budget constraints. These models can solve more practical problems and the input variables are generally deterministic.

LCC analysis always include elements of uncertainty because a part of the input data has to be defined on the basis of different estimations and assumptions about the development of costs and revenues in a long term. It has been recognized that probability methods are useful in handling uncertainty in cost models. Thus, instead of treating the input variables as fixed, such as performance, quality, costs and price requirements, it is more appropriate to quantify them in terms of probability distribution functions. The Monte Carlo method includes all roceedings that aim to find approximate solutions for some problems (mathematical, technical or operational). The Monte Carlo method involves estimating the probability of occurrence of certain events based on previous studies[17, 19]. According to Emblemsvag [8], the Monte Carlo simulation is an especially useful method for cost management purposes. Consequently, Monte Carlo analysis is an ideal method for quantifying parameter uncertainty in LCC studies. On this paper, the LCC method is combined with Monte Carlo Simulation using real data for comparative analysis of maintenance costs between two urban transport fleets in two countries: Spain and Brazil.

\section{Methodology}

\subsection{Model formulation}

Being $f(x, y)$ a function that represents the total maintenance and operational cost for a single bus, it is converted to actual value since the beginning from its operational life, until it reaches simultaneously the age " $x$ " and the total mileage " $y$ ". So, the description of the problem consists in finding the best fit between the age and mileage $\left(x^{*}, y^{*}\right)$ that comes to be the optimal fleet replacement point using the Life cycle cost (LCC) analysis, as well as the Monte Carlo method, which inserts random variables in the total maintenance and operational cost model. For the LLC analysis, the first step is to define the entire cash flow in function of $G(\boldsymbol{x}, \boldsymbol{y})$, as shown in the equation (1):

$$
G(x, y)=f(x, y)+V c-V R
$$

Being:

$$
\begin{aligned}
& \text { Vc: Purchase Cost } \\
& \text { VR: Resale value }
\end{aligned}
$$

Once the cash flow is defined, it is necessary to find out age and mileage $\left(\boldsymbol{x}^{*}, \boldsymbol{y}^{*}\right)$ for the optimal fleet replacement, which means to find the lower values of the average annual cost per mile (AAC), defined in the equation below:

$$
H(x, y)=\frac{G(x, y)}{x * y}
$$

So, the problem can be written as:

$$
(P 1)\left\{\begin{array}{l}
\text { Find }(x, y) \in R^{2}, \text { suchas } \\
(x, y)=\arg \min [H(x, y)]
\end{array}\right.
$$

Being:

$$
\begin{aligned}
& x \in\left[x_{\text {min }}, y_{\text {min }}\right] \\
& y \in\left[x_{\text {min }}, y_{\text {min }}\right] \\
& x_{\text {min }}, x_{\text {max }}, y_{\text {min }}, y_{\text {max }} \in R
\end{aligned}
$$

The problem studied in this work considers variations in the cost function that have no predictability or a well-defined pattern. Thus, random modeling will be used for estimation. The problem is defined as $(\boldsymbol{x}, \boldsymbol{y}) \boldsymbol{X}(\boldsymbol{\Omega}, \boldsymbol{F} . \boldsymbol{P})$, in which " $\boldsymbol{\Omega}$ " is the sample space of events, " $F$ " the algebra of events, and " $P$ " a probability measure. From this the following hypotheses are necessary:

$H 1)$ The total cost function is differentiable;

H2) The random variables that define the cost function are limited and statistically independent [1].

As a result, the problem $P 1$ is reformulated as:

$$
(P 2)\left\{\begin{array}{c}
\text { Find }\left(x^{*}, y^{*}\right) \in\left[R^{2}, P\right], \text { such as } \\
\left(x^{*}, y^{*}\right)=\arg \min [H(x, y, w)] \\
(x, y, w) \in R^{2} X(\Omega, F . P)
\end{array}\right.
$$

The problem defined in Eq. (4) will be solved through Monte Carlo simulation-based methods. This kind of method is developed in three stages:

I Generate, according to the probability functions of each parameter, $N$ - samples of random variables that model the uncertainty on the parameters that define the function total cost;

II For the sample of the parameters, solve the following problem: 


$$
(P 3)\left\{\begin{array}{c}
\text { Find }\left(x_{i}^{*}, y_{i}^{*}\right) \in\left[R^{2}, P\right], \text { such as } \\
\left(x_{i}^{*}, y_{i}^{*}\right)=\arg \min [H(x, y, w)] ; \\
(x, y, w) \in R^{2} X(\Omega, F . P)
\end{array}\right.
$$

III With all these results, analyze the final result with the graphical distribution from the function $\boldsymbol{H}_{\boldsymbol{i}}^{*}\left(x_{i}^{*}, y_{i}^{*}\right)$ and the variables $x_{i}^{*}$ and $\mathrm{y}_{\mathrm{i}}^{*}$.

In order to generate a model that forecasts the total cost of maintenance and operating simultaneously in function of age and mileage $\boldsymbol{f}(\boldsymbol{x}, \boldsymbol{y})$, a regression analysis was developed. Besides, this analysis employing algorithms of minimum distance was carried out using the software ${ }^{\circledR}$ Minitab, in order to find out the best arrangement through a mathematical function. The kind of equation elected to be used in this model was made with respect to the quality and quantity of available data. For the Spanish fleet, in which the data were more abundant in terms of years, a quadratic function was applied (formula 6). Nevertheless, as the Brazilian fleet lacks the same quantity of data, an exponential function was employed in order to have a representative function (formula 8). In order to analyze the parameter's variations that the deterministic approach can't assess, the Monte Carlo simulation will be employed.

\subsubsection{The Spanish Urban Transport Fleet}

$$
f(x, y)=a^{*} x^{2}+b^{*} y^{2}+c^{*} x^{*} y+d^{*} x+e^{*} y+f
$$

Where:

$$
a, b, c, d, e, f \in R
$$

According to this, the constants from the quadratic function will be considered as uniform random variables with a " $p$ " variation of the data field:

$$
X_{i} \in\left[(\mathbf{1}-\boldsymbol{p}) * x_{i} ;(\mathbf{1}+\boldsymbol{p}) * x_{i}\right]
$$

Where:

$X_{i}$ : Set of possible results for a random variable $\mathrm{x} \_\mathrm{i}$.

Where: $x_{i}=a ; x_{i}=b ; x_{i}=c ; x_{i}=d ; x_{i}=e ; x_{i}=f$ and $\boldsymbol{p} \in[\mathbf{0} ; \mathbf{1}]$.

\subsubsection{The Brazilian Urban Transport Fleet}

$$
f(x, y)=a * x * e^{(b * y)}
$$

Where:

$$
\boldsymbol{a}, \boldsymbol{b} \in \boldsymbol{R}
$$

The constants from the exponential function will be considered as uniform random variables with a " $p$ " variation of the data field:

$$
X_{i} \in\left[(1-p) * x_{i} ;(1+p) * x_{i}\right]
$$

Where:

Set of possible results for a random variable

Where: $x_{i}=a ; x_{i}=b$ and $\boldsymbol{p} \in[\mathbf{0} ; \mathbf{1}]$.

\subsection{Database analysis}

\subsubsection{The Spanish Urban Transport Fleet}

A sample of 34 vehicles was selected and named as "Type A" vehicles. The buses belonging to this sample have the same technical characteristics, mechanical configurations, fuel, and they were exposed to similar operating conditions, such as average speed, stops per mileage, passenger loading, climate conditions, and the largest mileage during lifespan. The analysis period considered was of 10 years (2005-2014), and all the costs were converted and updated using the Spanish economic indicators. The results obtained were extrapolated to the entire lifespan of the vehicles.

The following restraints were applied and considered:

1) Averaged fuel consumption was considered as a constant along the vehicle's lifespan.

2) Annual averaged mileage was constant and determined through all sample selection buses. For this work, the annual average mileage was taken as $61.597 \mathrm{~km} /$ year.

3) In order to determine the operational costs, fuel, insurance and tax costs were summed up.

4) Resale Value ( $\boldsymbol{V} \boldsymbol{R})$ was calculated by a linear model used by the company and based on its own experience, which is obtained by formula 10 :

$$
V R=R+\left[\frac{V_{c}-R}{N} * 0.7778 * R v\right]
$$

Where:

0,7778 Factor dependent on service conditions.

$R_{v}=$ Remaining vehicle's life.

$(R)$ Residual Value: In accounting, residual value is another name for salvage value, the remaining value of an asset after being fully depreciated. The formula to calculate the residual value for this case study was established in $10 \%$ of the purchase cost.

$(V c)$ Purchase Cost: the investment cost considered to acquire a new vehicle, similar as type A. To simplify, the investment was considered paid in full at the purchase moment. Value: $€$ $\mathbf{2 4 0 . 0 0 0 , 0 0 .}$

$(N)$ Estimated Lifespan: The estimated age indicated by the company and adopted for this study was $\mathbf{1 4}$ years, which is similar to those ones used by other Spanish companies. Notice that this parameter is above the average value in other countries such as the United States, France and Italy, where the considered vehicles' lifespan is 12 years. Probably, the very important economic crisis suffered by Spain on this period can be the explanation for this increase on the estimated lifespan.

\subsubsection{The Brazilian Urban Transport Fleet}

A sample of 33 vehicles was selected and named as "Type B" vehicles. The buses belonging to the sample have the same technical characteristics, mechanical configurations, fuel, and they were exposed to similar operating conditions such as average speed, stops per mileage, passenger loading, climate conditions, and the largest mileage during lifespan. The analysis period considered was of 05 years (2011-2015). The results obtained were extrapolated to the entire lifespan of the vehicles. The following restraints were applied and considered:

1. Averaged fuel consumption was considered as a constant along the vehicle's lifespan. 
2. Annual averaged mileage was constant and determined through all sample selected buses. For this work, the annual average mileage was taken as $80.620 \mathrm{~km} / \mathrm{year}$.

3. In order to determine the operational costs, only the fuel cost was taken into account, as the company previously decided.

4. Resale Value (VR) was taken in the same way as in the Spanish fleet formula 10 , and:

$(V c)$ Purchase Cost: Value $€$ 103.926,10.

$(N)$ Estimated Lifespan: The estimated age indicated by the company and adopted for this study was $\mathbf{1 2}$ years, which is set by the local legislation.

\section{Results}

For a better understanding, the optimum replacement moment was at first determined by using the conventional Life Cycle Cost Analysis (LCC) methodology. After that, an analysis using the Monte Carlo method was performed and, finally, the results can be compared.

\subsection{Life Cycle Cost Analysis}

For this case study, some aspect should be taken into account:

1. The maintenance costs were selected and adjusted based on Extrapolation Mathematics Technique, in order to obtain a set of observations and to extend this pattern into the future.

2. The Total Accumulated Cost (TAC) until a certain year is the result of the total investment cost plus the maintenance and operating costs. All the costs were accumulated until that year less the resale value of the same year.
3. The Average Annual Cost (AAC) indicates the cost accrued until the vehicle's life, divided by its lifetime thereof, so that the minimum average annual cost will determine the optimal time for the vehicle's renewal, which presents the lowest possible cost for the vehicle operation (formula 10).

$A A C=\frac{\left[\sum \text { Investment }+\sum \text { Maintenance }+\sum \text { Operating }-(\text { ResaleValue })\right]}{n(\text { year })}$

\section{Results of the LCC Method}

The cost development and analysis for the Spanish and the Brazilian fleets are shown in Tables 1 and 2 respectively

\subsubsection{The Spanish Urban Transport Fleet}

In summary, the results indicate that the minimal Average Annual Cost per kilometer (AAC) is shown to the Spanish fleet in the 7th year $(\mathbf{1 , 0 2} € / \mathbf{k m})$, to the Brazilian fleet in the 5 th year $(\mathbf{0 , 3 9 3} € / \mathbf{k m})$.

\subsection{Monte Carlo Simulation}

The method was developed considering a contraint in the annual milleage between $55.000 \mathrm{~km}$ and $80.000 \mathrm{~km}$ for the Spanish fleet (Scenario1), and between $60.000 \mathrm{~km}$ and $100.000 \mathrm{~km}$ for the Brazilian fleet (Scenario 2). This technique gives a reliable mathematical basis for solutions derived from individual scenarios, and it can be applied to linear problems in order to improve pure scenario analysis.

Table 2. Brazilian Fleet

\begin{tabular}{|c|c|c|c|c|c|c|c|c|c|c|c|c|}
\hline $\begin{array}{l}\text { Year } \\
\text { (n) }\end{array}$ & & $\begin{array}{l}\text { Purchase } \\
\text { Cost }\end{array}$ & & $\begin{array}{l}\text { ntenance } \\
\text { Cost }\end{array}$ & $\begin{array}{c}\sum \text { Operation } \\
\text { Cost }\end{array}$ & & $\begin{array}{l}\text { R Res ale } \\
\text { Value }\end{array}$ & & TAC & & $\triangle A C$ & AAC/k m \\
\hline 1 & $\epsilon$ & $103.926,10$ & $\epsilon$ & $2.572,82$ & $€ 17.106,53$ & $€$ & $77.080,43$ & C & $46.525,02$ & $€$ & 5,02 & $€ 0,575$ \\
\hline 2 & $€$ & $103.926,10$ & $€$ & 04 & $€ \quad 33.5$ & - & 0 & - & & $€$ & 05 & $€ \quad 0,446$ \\
\hline 3 & $€$ & $103.926,10$ & 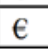 & & $€ 50.8$ & $c$ & & $€$ & & $€$ & & $€ \quad 0,409$ \\
\hline 4 & $€$ & $103.926,10$ & $€$ & 14.0 & $€ \quad 69.013,23$ & $€$ & $58.892,84$ & $€$ & 128.0 & $€$ & 43 & $€ \quad 0,396$ \\
\hline 5 & $\epsilon$ & $103.926,10$ & $\epsilon$ & $19.557,31$ & $\in 88.432,13$ & 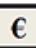 & $52.830,31$ & $t$ & 159. & $\epsilon$ & $31.817,05$ & $\epsilon 0,393$ \\
\hline 6 & $€$ & 20 & $€$ & & $€ 108.4$ & $€$ & & $\epsilon$ & & $€$ & & $€ \quad 0,395$ \\
\hline 7 & $€$ & $103.926,10$ & $€$ & $34.360,85$ & $€ 128.4$ & $€$ & 40.7 & $\epsilon$ & 70 & $€$ & 2,10 & $€ \quad 0,399$ \\
\hline 8 & $€$ & $103.926,10$ & $€$ & & $€ 148.478,45$ & - & $34.642,73$ & $€$ & & $€$ & & $€ 0,405$ \\
\hline 9 & $€$ & $103.926,10$ & $€$ & $56.064,19$ & $€ 168.493,89$ & $€$ & $28.580,20$ & $€$ & $299.903,98$ & $€$ & $33.322,66$ & $€ \quad 0,412$ \\
\hline 10 & $\epsilon$ & $103.926,10$ & $€$ & $70.456,61$ & $€ 188.509,33$ & $€$ & $22.517,67$ & $€$ & $340.374,37$ & $€$ & $34.037,44$ & $€ \quad 0,421$ \\
\hline 11 & $\epsilon$ & $103.926,10$ & $€$ & $87.883,28$ & $€ 208.524,77$ & $€$ & $16.455,14$ & $\epsilon$ & $383.879,00$ & $€$ & $34.898,09$ & $€ \quad 0,431$ \\
\hline 12 & $€$ & $103.926,10$ & $€$ & $108.983,88$ & $€ 228.540,20$ & $€$ & $10.392,61$ & $€$ & $431.057,57$ & $€$ & $35.921,46$ & $€ \quad 0,444$ \\
\hline
\end{tabular}

Table 1. Spanish Fleet

\begin{tabular}{|c|c|c|c|c|c|c|c|c|c|c|c|c|}
\hline $\begin{array}{l}\text { Year } \\
\text { (n) }\end{array}$ & \multicolumn{2}{|c|}{$\begin{array}{c}\sum \text { Purchase } \\
\text { Cost }\end{array}$} & \multicolumn{2}{|c|}{$\begin{array}{c}\sum \text { Mainte nance } \\
\text { Cost }\end{array}$} & $\begin{array}{c}\sum \text { Operation } \\
\text { Cost }\end{array}$ & $\begin{array}{c}\text { VR Resale } \\
\text { Value } \\
\end{array}$ & \multicolumn{2}{|r|}{ TAC } & \multicolumn{2}{|r|}{ AAC } & \multicolumn{2}{|c|}{ AAC $/ \mathbf{k m}$} \\
\hline 1 & $€$ & $240.000,00$ & $€$ & $8.581,30$ & $€ \quad 30.143,09$ & $€ 180.656,22$ & $\epsilon$ & $98.068,16$ & $€$ & $98.938,36$ & $€$ & 1,61 \\
\hline 2 & $€$ & $240.000,00$ & $€$ & $17.913,63$ & $€ 62.778,49$ & $€ 168.612,43$ & $€$ & $152.079,69$ & $\epsilon$ & $76.475,59$ & $€$ & 1,24 \\
\hline 3 & $€$ & $240.000,00$ & $€$ & $28.062,72$ & $€ 96.514,27$ & $€ 156.568,64$ & $€$ & $208.008,36$ & $\tau$ & $69.627,09$ & $€$ & 1,13 \\
\hline 4 & $€$ & $240.000,00$ & $€$ & $39.100,07$ & $€ 129.365,81$ & $€ 144.524,84$ & $€$ & $263.941,04$ & $t$ & $66.203,87$ & $€$ & 1,07 \\
\hline 5 & $€$ & $240.000,00$ & $€$ & $51.103,41$ & $€ 166.922,78$ & $€ 132.481,05$ & $€$ &, 15 & &, 25 & $€$ & 1,06 \\
\hline 6 & $€$ & $240.000,00$ & $€$ & $64.157,28$ & $€ 196.474,96$ & $€ 120.437,25$ & $€$ & $380.194,99$ & $t$ & $63.512,15$ & $€$ & 1,03 \\
\hline 7 & $€$ & $240.000,00$ & $€$ & $78.353,63$ & $€ 229.795,11$ & $€ 108.393,46$ & $€$ & 439.755,29 & $€$ & $62.947,89$ & $€$ & 1,02 \\
\hline 8 & $€$ & $240.000,00$ & $€$ & $93.792,45$ & $€ 267.635,53$ & $€ 96.349,66$ & $€$ & $505.078,32$ & & $63.245,05$ & $c$ & 1,03 \\
\hline 9 & $€$ & $240.000,00$ & $€$ & $110.582,47$ & $€ 307.604,76$ & $€ \quad 84.305,87$ & $€$ & $573.881,36$ & $€$ & $63.862,86$ & $€$ & 1,04 \\
\hline 10 & $€$ & $240.000,00$ & $€$ & $128.841,96$ & $€ 346.550,49$ & $€ \quad 72.262,08$ & $€$ & $643.130,38$ & $€$ & $64.401,73$ & $€$ & 1,05 \\
\hline 11 & $€$ & $240.000,00$ & $€$ & $148.699,52$ & $€ 384.039,34$ & $€ \quad 60.218,28$ & $€$ & $712.520,58$ & $€$ & $64.855,48$ & $€$ & 1,05 \\
\hline 12 & $€$ & $240.000,00$ & $€$ & $170.295,02$ & $€ 423.066,24$ & $€ \quad 48.174,49$ & $€$ & $785.186,77$ & 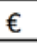 & $65.506,63$ & $€$ & 1,06 \\
\hline 13 & $€$ & $240.000,00$ & $€$ & $193.780,56$ & $€ 462.093,14$ & $€ \quad 36.130,69$ & $€$ & $859.743,00$ & $€$ & $66.203,00$ & $€$ & 1,07 \\
\hline 14 & $€$ & $240.000,00$ & $€$ & $219.321,56$ & $€ 501.120,04$ & $€ \quad 24.086,90$ & $€$ & $936.354,70$ & $€$ & $66.946,73$ & $€$ & 1,09 \\
\hline
\end{tabular}


The data used for the development of the Monte Carlo methodology were processed by using software Matlab.

\section{Results of the Monte Carlo Method}

\section{i Age Indicated}

The ages indicated for replacement fleet that came from this methodology are graphed in a histogram (figure 2).

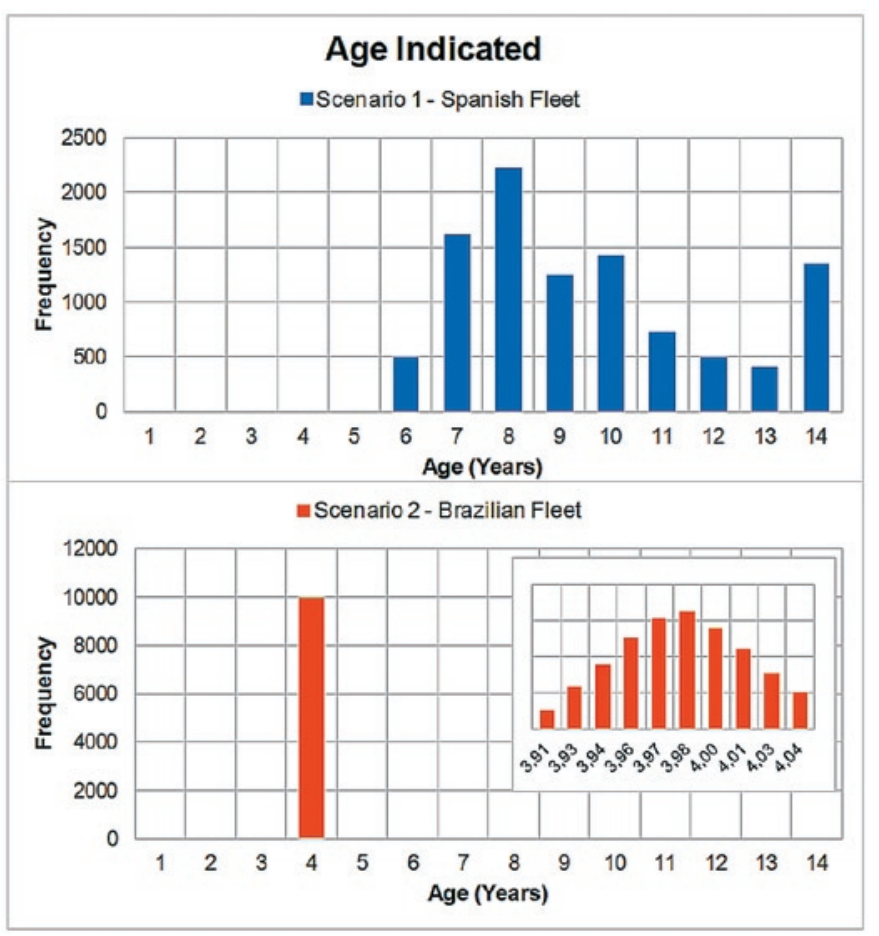

Fig. 2. Age Indicated

The analysis of the histograms for both scenarios show us which of them is the best option for the replacement decision, taking into account the previously defined restrictions. For the Spanish fleet, the $8^{\text {th }}$ year is clearly the most convenient option. For the Brazilian fleet, the $3,98^{\text {th }}$ year is the highest value, although for practical reasons the $4^{\text {th }}$ year is an accurate approximation.

\section{ii Mileage Indicated}

The mileages indicated for replacement fleet were obtained using this method and they are graphed as shown in the histogram (figure 3).

The histogram's analysis of Scenario 1, which presents the best mileage to be used by the vehicle, shows that the values in $\mathrm{km}$ are inclined to the established value of $80.000 \mathrm{~km}$ (simulation's restraining

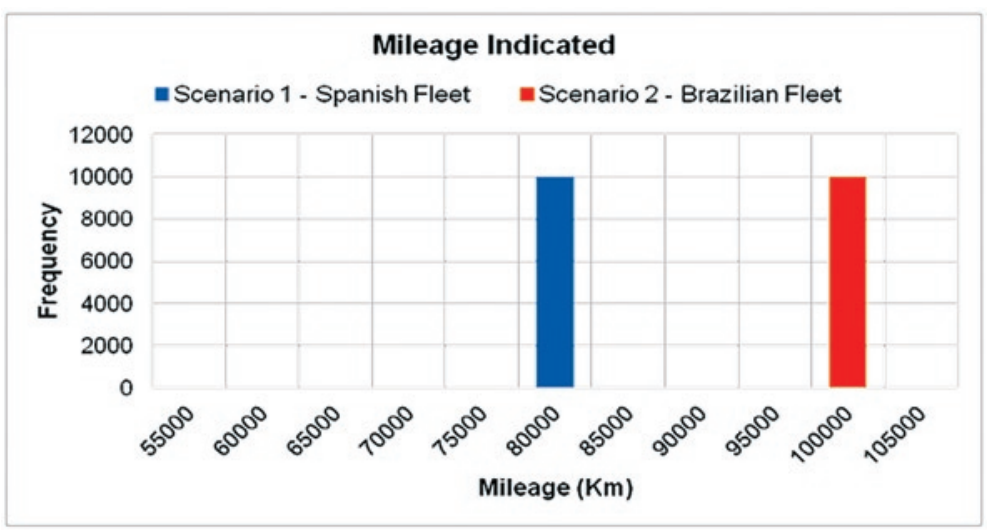

condition), and the same trend occurs on the second scenario, which obtains $100.000 \mathrm{Km}$ for ideal annual milleage. This indicates that the restraining conditions don't represent the minimal cost real points of an unrestrained scenario. An unrestrained analysis shouldn't be perfomed because the database had no information about these regions, thus, any inference would not be precise.

\section{iii General Cost Analysis}

This analysis shows which parameter(s) would be the best for the fleet's vehicle use during its lifespan in order to optimize its costs. For this analysis, some parameters are correlated: Annual Mileage, Age of the vehicle and the Annual Average Cost (AAC). Figure 4 shows one sample out of ten thousand possibilities obtained in the scenario 1 (Spanish Fleet). Besides, figure 5 shows the similar analysis for the scenario 2 (Brazilian Fleet). For both figures, the age of replacement is represented in the axis of the abscissa while the average annual mileage is represented in the axis of the ordinates and the annual average cost (AAC), calculated by the function above mentioned in equa-

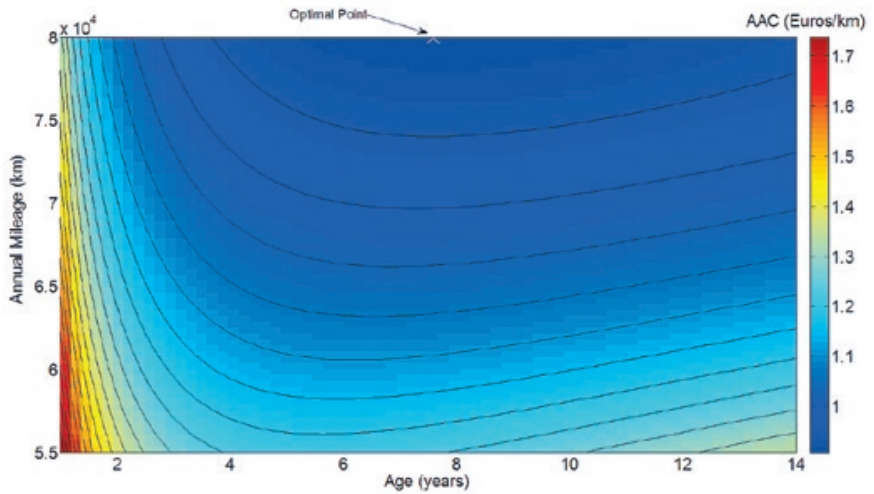

Fig. 4. Spanish Fleet Sample

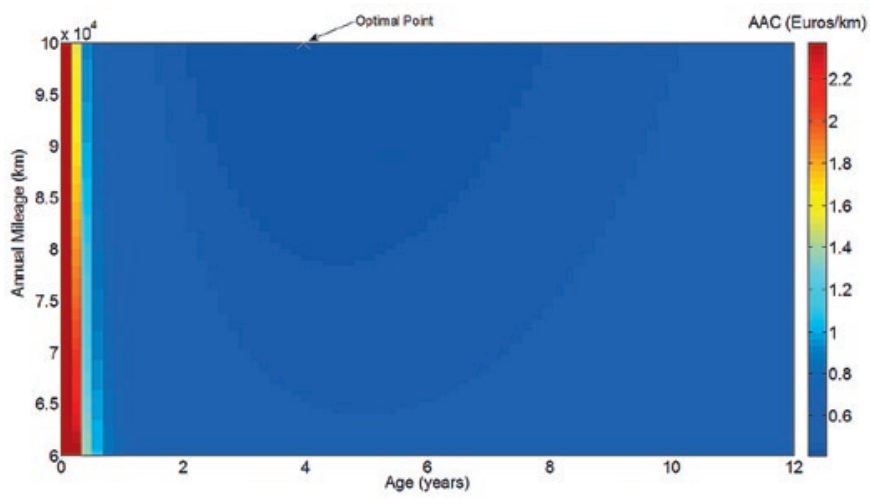

Fig. 5. Brazilian Fleet Sample

tion 2 , is represented by color grading of the intersection point, ranging from dark blue for lower costs to red for higher costs. Furthermore, the figure 4 and 5 indicate the best fit between age and mileage, that minimizing the value of the AAC.

Despite the capacity of indicating the optimal point, this analysis also demonstrates other combinations over its lifespan, and it might effectively support fleet managers to develope their strategies and activities, especially when the fleet managers need to access the trade-off between costs and benefits related to different parameters. Furthermore, a comparison between the Spanish and the Brazilian results could be realized, as it's shown below (table 3 ), based on figure 4 and 5 .

Fig. 3. Mileage Indicated 
Table 3. Fleets Comparison

\begin{tabular}{|c|c|c||}
\hline & Spanish Fleet & Brazilian Fleet \\
\hline Age & 8 years & 4 years \\
\hline Annual Mileage & $80.000 \mathrm{~km}$ & $100.000 \mathrm{~km}$ \\
\hline Cost per Km & $\approx € 1,00$ & $\approx € 0,50$ \\
\hline & & \\
\hline
\end{tabular}

\section{Conclusion}

The association of these two models allows not only the evaluation of the proper replacement moment, but also a general cost analysis over the fleet's useful life, which indicates the age, mileage driven, and the unit cost per mileage in an organized and simultaneous way over the vehicle's useful life. Therefore this research provides the management with the evaluation of the vehicle's life cycles, since it is a tool that assesses the replacement decision of the vehicles for a similar one. The final replacement decision should take into account not only economic criteria, but also a variety of factors which are different from those previously studied, such as fleet's size, real mileage, number of workers and passengers, service quality, governmental transport policies, environment, annual budget, among others. For this case study, the cost per kilometer is much lower to the Brazilian fleet probably due to the lower purchase price, lower costs with fleet labour, fuel, as well as lower direct costs for maintenance, if in comparison to the costs in Spain. Besides, it is important to consider the devalued exchange rate Real/Euro $(€ 1,00=\mathrm{R} \$ 4,33)$, and the inferiority in terms of available technology and luxury of the Brazilian fleet compared to the Spanish.

Regarding replacement, it may occur sooner in the Brazilian fleet, basically because of the difficult enviromental conditons and the traffic that the fleet is subjected to.Therefore, these features and a higher level of use overload the fleet. Finally, another possible function of this model, which will be studied on future researches, could be used to improve the management decision process with an ideal replacement strategy, regarding how many and which vehicles should be replaced.

\section{References}

1. Avila C R, Beck A T. New method for efficient Monte Carlo-Neumann solution of linear stochastic systems. Probabilistic Engineering Mechanics 2015; 40: 90-96, http://dx.doi.org/10.1016/j.probengmech.2015.02.006.

2. Banar M, Özdemir A. An evaluation of railway passenger transport in Turkey using life cycle assessment and life cycle cost methods. Transportation Research Part D 2015; 41: 88-105, http://dx.doi.org/10.1016/j.trd.2015.09.017.

3. Boudart J, Figliozzi M. Key Variables Affecting Decisions of Bus Replacement Age and Total Costs. Transportation Research Board 2012. 2274: 109-113, http://dx.doi.org/10.3141/2274-12.

4. Clark N N, Zhen F, Wayne S W. Assessment of Hybrid-Electric Transit Bus Technology. Washington D.C. Transportation Research Board 2009.

5. Collan M, LIU S. Fuzzy Logic and Intelligent Agents: Towards the next step of capital budgeting decision support. Industrial Management Data Systems 2003: 103: 410-424, https://doi.org/10.1108/02635570310479981.

6. Di J, Hauke L. Optimal Fleet Utilization and Replacement. Transportation Research Part E 2000: 36(1): 3-20, https://doi.org/10.1016/S13665545(99)00021-6.

7. Dhillon B S. Life Cycle Costing For Engineers. London: CRC Press 2010.

8. Emblemsvag J. Life-Cycle Costing, Using Activity-based Carlo, Monte To, Methods Costs, Manage Future. Hoboken New Jersey-USA: John Wiley \& Sons, Inc. 2003.

9. Fan W, Randy M, Gemar M, Brown L. A Stochastic Dynamic Programming Approach for the Equipment Replacement Optimization with Probabilistic Vehicle Utilization. The 91st Annual Meeting of Transportation Research Board. Washington D.C. 2012.

10. Feng W, Figliozzi M. An economic and technological analysis of the key factors affecting the competitiveness of electric commercial vehicles: A case study from the USA market. Transportation Research Part C: Emerging Technologies 2012; 26: 135-145, https://doi.org/10.1016/j. trc.2012.06.007.

11. Gransberg D, O'Connor E. Major Equipment Life-cycle Cost Analysis. Institute for Transportation Iowa State University. Minnesota Department of Transportation Research Services \& Library, USA 2015.

12. Khasnabis S, Alsaidi E, Ellis R D. Optimal allocation of resources to meet transit fleet requirements. Journal of Transportation Engineering 2002; 128(6): 509 -518, https://doi.org/10.1061/(ASCE)0733-947X(2002)128:6(509).

13. Kim D S., Porter D J, Kriett P, Mbugua W, Wagner T. Fleet Replacement Modeling. Final Report, Oregon State University, School of Mechanical, Industrial and Manufacturing Engineering 2009.

14. Laver R, Schneck D, Skorupski D, Brady S, Cham L, Hamilton B A. Useful Life of Transit Buses and Vans. Washington D.C: Federal Transit Administration 2007.

15. Nowakowski T, Młyńczak M, Werbińska-Wojciechowska S, Dziaduch I, Tubis A. Life Cycle Costs of passenger transportation system. Case study of Wroclaw city agglomeration 5. JPSRA 2014; 5: 109-120.

16. Pinar Keles, Hartman J C. Case Study: Bus Fleet Replacement. The Engineering Economist 2004; 49(3): 253-278, https://doi. org/10.1080/00137910490498951.

17. Rymarz J, Niewczas A, Krzyżak A. Comparison of operational availability of public city buses by analysis of variance. Eksploatacja i Niezawodnosc-Maintenance and Reliability 2016; 18 (3):373-378, http://dx. doi.org/10.17531/ein.2016.3.8.

18. Singh D, Tiong R L K. Development of life cycle costing framework for highway bridges in Myanmar. International Journal of Project Management 2005; 23: 37-44, http://dx.doi:10.1016/j.ijproman.2004.05.010.

19. Tchórzewska-Cieślak B, Pietrucha-Urbanik K, Urbanik M. Analysis of the gas network failure and failure prediction using the Monte Carlo simulation method. Eksploatacja i Niezawodnosc - Maintenance and Reliability 2016; 18 (2): 254-259, http://dx.doi.org/10.17531/ ein.2016.2.13. 


\section{Vicente MACIÁN}

CMT Motores Térmicos

Universitat Politècnica de València

Camino de Vera, s/n, 46022, Valencia - Spain

\section{Bernardo TORMOS}

CMT Motores Térmicos

Universitat Politècnica de València

Camino de Vera, s/n, 46022, Valencia - Spain

\section{Jorge RIECHI}

Department of Mechanical Engineering

Federal Technological University of Paraná

Av 7 de setembro, 3165, 80230-901- Curitiba - Paraná - Brazil

E-mails:vmacian@mot.upv.es, betormos@mot.upv.es, riechi@utfpr.edu.br 